\title{
Growth, instability and forecast of marine products export from India
}

\author{
APU DAS, NALINI RANJAN KUMARAND PRATHVI RANI \\ ICAR-Central Institute of Fisheries Education, Versova, Mumbai - 400 061, Maharashtra, India \\ e-mail: apudasfo@gmail.com
}

\begin{abstract}
This paper analysed growth and instability in export of marine products from India with an attempt to forecast the total export quantity of marine products from the country. The compound growth rates and instability indices of marine products export from India were estimated for major importing countries viz., Japan, USA, European Union, South-east Asia and Middle East; as more than $80 \%$ of the marine products export from India destines to these markets. The study revealed high compound growth rate and low instability in case of selected countries. The study also revealed that India's marine products export concentrated mainly to those countries, which were falling in less desirable or least desirable category which has affected export performance of the country. Forecast of India's marine products export was done by fitting univariate Auto Regressive Integrated Moving Average (ARIMA) models. ARIMA $(1,1,0)$ was found suitable for modelling marine products export from India. The results of ARIMA model indicated increasing trend in export of Indian marine products. This calls for serious attention by policy makers to identify competitive and stable market destinations for marine products export which could help in harnessing the potential of marine products export from India.
\end{abstract}

Keywords: Auto regressive integrated moving average model (ARIMA), Compound growth rate (CGR), Forecast, Instability index, Marine products export

\section{Introduction}

Marine products play an important role in Indian export earnings. During 2014-15, the export earnings from marine products crossed 5.5 billion USD, aggregated to $1,05,1243 \mathrm{t}$ in volume and ₹33,441 crores in value. Compared to the previous year, seafood exports recorded a growth of $6.86 \%$ in quantity, $10.69 \%$ in rupee and $10.05 \%$ in US\$ earnings, respectively (MPEDA, 2016). This indicates potential for increasing marine products export from India. Harnessing this potential requires strategic planning to focus on strategic markets and products. The present study attempted to analyse growth and instability in export of Indian marine products to major importing countries viz., Japan, USA, South-east Asia, European Union and Middle East, in order to identify the most desirable destination for marine products export from India. Considering the importance of marine products export in Indian economy, the forecast of marine products export in terms of quantity was also attempted using ARIMA models, to provide tentative figure of export for the years to come. This will enable the policy makers and exporters to plan for adequate quantity of exportable surplus every year.

\section{Materials and methods}

The data on marine products export of India for a period of 40 years from 1975 to 2014 was collected
(MPEDA, 2016; Inidastat, 2016). Countrywise time series export data was also collected for last 10 years from 2004 to 2014. The major five importing countries selected for the study were Japan, USA, European Union, South-east Asia and Middle East.

The growth in terms of quantity exported and export value realised from exports were analysed using the exponential growth function (Salim and Biradar, 2009) of the form:

$\mathrm{Y}=a b^{t} e_{t}$

where, $\mathrm{Y}=$ dependent variable for which growth rate was estimated; $a=$ Intercept; $\quad b=$ Regression coefficient; $\mathrm{t}=$ time variable and $\mathrm{e}=$ Error term

The compound growth rate was obtained for the logarithmic form of the equation as:

In $Y=\operatorname{Ln} a+t \operatorname{Ln} b$

The compound growth rate (r) was computed by using the relationship:

$r=($ Anti Ln of 'b' - 1) x 100

There are a number of techniques available to measure the index of instability (Coppock, 1962; MacBean, 1966; Massel, 1970; Weber and Sievers, 1983; Singh and Byerlee, 1990; Parthasarathy, 1984; Wasim,1999). In this study, Coppock's instability index (CII) (Chand and Tewari (1991); Wasim, 2007; Reddy et al., 2010; Fauzi, 
2012) was calculated to assess the instability, as follows:

$\mathrm{CII}=[$ Antilog $\sqrt{ } \log \mathrm{V}-1] \times 100$

where, $\log \mathrm{V}=\frac{1}{(\mathrm{n}-1)}\left[\sum\left(\log \mathrm{x}_{\mathrm{t}+1}-\log \mathrm{x}_{\mathrm{t}}\right)-\frac{1}{(\mathrm{n}-1)} \sum\left(\log \mathrm{x}_{\mathrm{t}+1}-\log \mathrm{x}_{\mathrm{t}}\right)\right]$,

$\mathrm{n}=$ number of years, $\mathrm{x}=$ value of the variable being observed and $\mathrm{t}=$ year.

While calculating compound annual growth rate (CGR) and CII for value gains against quantity exported to a particular country, the money value was deflated to the year 2004 using consumer price index which was also used by Bryan and Cecchetti (1993) and deflated values are presented in Table 1.

Risk assessment of Indian marine products export was done by looking at the relation between growth and instability, graphically and by classifying the importing countries into high growth-low risk, high growth-high risk, low growth-low risk and low growth-high risk categories (Reddy et al., 2010; Jeyanthi and Nikita, 2012)

In general, an ARIMA model is characterised by the notation ARIMA ( $p, d, q$ ) where $p, d$ and $q$ denote orders of auto-regression, integration (differencing) and moving average respectively. In ARIMA, time series is a liner function of past actual values and random shocks. A stationary ARIMA (p, q) process is defined by the equation:

$\mathrm{Y}_{\mathrm{t}}=\beta_{0}+\beta_{1} \mathrm{Y}_{\mathrm{t}-1}+\beta_{2} \mathrm{Y}_{\mathrm{t}-2}+\ldots \ldots+\beta_{\mathrm{n}} \mathrm{Y}_{\mathrm{t}-\mathrm{n}}+\varepsilon_{\mathrm{t}} \omega_{1} \varepsilon_{\mathrm{t}-1}-\omega_{2} \varepsilon_{\mathrm{t}-2} \ldots \ldots \omega_{\mathrm{n}} \varepsilon_{\mathrm{t}-\mathrm{n}}$

where, $Y_{t}$ is the response (dependant) variable at time ' $t$ '. $\mathrm{Y}_{\mathrm{t}-1}, \mathrm{Y}_{\mathrm{t}-\mathrm{2}} \ldots \mathrm{Y}_{\mathrm{t}-\mathrm{n}}$ is the response (dependant) variable at time lags $t-1, \mathrm{t}-2, \ldots, \mathrm{t}-\mathrm{n}$ respectively; these $\mathrm{Y}$ 's are independent variables; $\beta_{1}, \beta_{2}, \ldots . \beta_{\mathrm{n}}$ are the coefficients to be estimated; $\varepsilon_{t}$ is the error term at time that represents the effects of variables not explained by the model; the assumptions about the error term are the same as those for the standard regression model. $\mathrm{e}_{\mathrm{t}-1}, \mathrm{e}_{\mathrm{t}-2} \ldots \mathrm{e}_{\mathrm{t}-\mathrm{n}}$ are the error terms that represent the effect of variables not explained by the model. The assumptions about the error term are the same as those for the standard regression model. $\omega_{1}$, $\omega_{2} \ldots \ldots \omega_{n}$ are the coefficients to be estimated.

The foremost step in the process of modelling is to check for the stationarity of the series, as the estimation procedures are available only for the stationary series. Visual examination of graph of the data and structure of auto correlation and partial correlation coefficients helps to check the presence of stationarity. Another way of checking for stationarity is to fit a first order auto regressive model for the raw data and test whether the coefficient ' $\beta$,' is less than one. If the model is found to be non-stationary, stationarity is achieved by differencing the series.

At the identification stage, one or more models were tentatively chosen that seem to provide statistically adequate representations of the available data. Then precise estimates of parameters of the model were obtained by least squares using SAS software for finding the estimates of relevant parameters using iterative procedures.

Different models were obtained for various combinations of auto regressive and moving average, individually and collectively. Best model was selected based on root mean square error (RMSE), mean absolute error (MAE), mean absolute percent error (MAPE), Bayesian information criterion (BIC) and significance of the parameters.

\section{Results and discussion}

Growth rate in Indian marine products export

The compound growth rate (CGR) and Coppock's instability index (CII) of Indian marine products export in terms of quantity and value during the period 2004-2014 for five major important markets were estimated (Table 2). CGR of quantity (CGR_Q) was found to be positive for all the countries. The CGR_Q was

Table 1. Countrywise deflated value of Indian marine products export to the year 2004

\begin{tabular}{|c|c|c|c|c|c|c|}
\hline \multirow{2}{*}{ Year } & \multirow{2}{*}{ Consumer price index (CPI) } & \multirow{2}{*}{ Japan } & \multirow{2}{*}{ USA } & \multirow{2}{*}{ EU } & \multicolumn{2}{|c|}{ (₹ crores) } \\
\hline & & & & & Middle East & South-east Asia \\
\hline 2004 & 63.95 & 1202.45 & 1556.00 & 1819.28 & 244.42 & 628.83 \\
\hline 2005 & 66.88 & 1105.33 & 1567.43 & 2040.75 & 294.17 & 560.18 \\
\hline 2006 & 71.29 & 1269.66 & 1264.43 & 2589.57 & 348.1 & 578.55 \\
\hline 2007 & 75.54 & 1158.52 & 959.73 & 2514.35 & 371.8 & 541.68 \\
\hline 2008 & 82.29 & 1132.78 & 937.76 & 2619.96 & 436.7 & 801.47 \\
\hline 2009 & 93.00 & 1141.07 & 895.92 & 2666.31 & 489.80 & 1309.16 \\
\hline 2010 & 100.00 & 1565.55 & 1850.94 & 3217.24 & 623.43 & 1966.47 \\
\hline 2011 & 109.47 & 1955.49 & 2719.95 & 3480.81 & 817.01 & 3830.52 \\
\hline 2012 & 120.14 & 1822.00 & 3668.88 & 3805.5 & 1014.46 & 3970.3 \\
\hline 2013 & 132.22 & 2238.73 & 7037.1 & 5569.66 & 1453.25 & 7311.43 \\
\hline 2014 & 138.48 & 2902.82 & 8430.95 & 6412.00 & 1929.51 & 8231.14 \\
\hline
\end{tabular}


Table 2. Compound growth rate (CGR) of Indian Marine products exports

\begin{tabular}{llllll}
\hline \multirow{2}{*}{ Country } & \multicolumn{2}{l}{ Export quantity (Q) } & & \multicolumn{2}{c}{ Export value (V) } \\
\cline { 2 - 3 } \cline { 5 - 6 } & CGR_Q & CII_Q & & CGR_V & CII_V \\
\hline Japan & 3.13 & 30.35 & & 9.21 & 56.46 \\
USA & 9.98 & 59.25 & & 18.40 & 85.87 \\
European union & 4.79 & 38.58 & & 13.42 & 70.78 \\
South-east Asia & 20.43 & 74.30 & & 29.32 & 94.84 \\
Middle East & 14.54 & 91.61 & & 22.95 & 98.47 \\
\hline
\end{tabular}

highest for South-east Asian countries (20.43\%), followed by Middle East countries (14.54\%), USA (9.98\%), European Union $(4.79 \%)$ and it was lowest for Japan (3.13\%). The CGR of value (CGR_V) was highest for South East Asian countries (29.32\%) followed by Middle East (22.95\%), USA (18.40\%), European Union (13.42\%) and the lowest for Japan (9.21\%).

\section{Instability in marine products export from India}

The level of instability in marine products export is very important for sustainable export. The estimated CII in marine products export for the period 2004-2014 is presented in Table 2. Instability index of quantity of export (CII_Q) was low for Japan (30.35\%). The growth also remained lowest among these countries and highest was observed for Middle East countries (91.61\%). The higher instability in quantity exported to Middle East (91.61\%) and South-east Asian countries (74.30\%) did not deter the concerned from attaining high growth rates. The export value instability (CII_V) of all the markets was found very high except for Japan $(56.46 \%)$ and European Union (70.78). Japan showed lowest instability index in all aspects viz., in terms of quantity and value and Middle East countries showed high instability in terms of both quantity exported to that country and for the value of the exported products. This again reinforces the fact that export value was mainly influenced by quantity exported. The fluctuation in quantity exported to Middle East

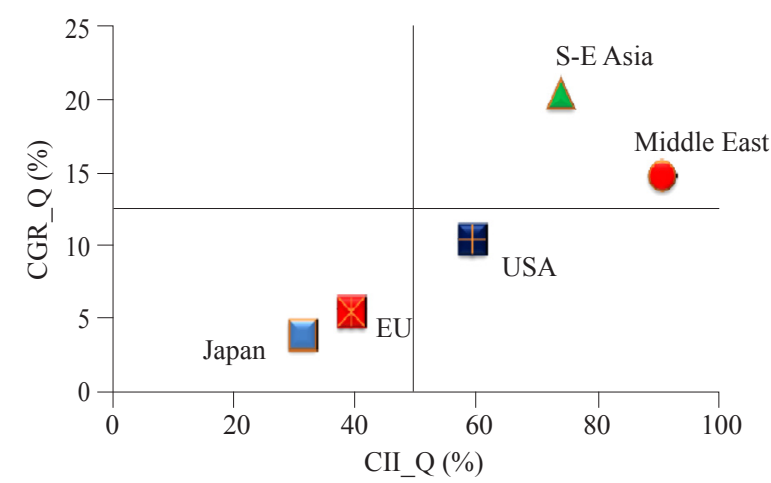

Fig. 1. Growth $v s$ instability of Indian marine products export in terms of quantity countries during 2007-2009 may be the main reason for high instability index.

\section{Risk assessment of Indian marine products export}

Risk assessment of Indian marine products export revealed that in terms of quantity; Middle East and South-east Asia were the less desirable countries falling in the high growth-high risk category. Japan and European Union were falling in low growth-low risk category, as indicated by the bottom left corner of Fig. 1. This pattern is undesirable from an economic point of view, since it indicates that export must be restrained. The markets like USA were the less desirable destinations falling in the low growth-high risk category and no markets were found in the most desirable high growth-low risk category for marine products export from India (Fig. 1). Since no country was found the most desirable category, efforts should be more concentrated towards the countries falling under less desirable category which have high growth like South-east Asia and Middle East countries with trade and non-trade barriers at ceteris paribus.

In terms of value, USA, Middle East and South-east Asia were less desirable falling in the high growth-high risk category and Japan falls in low growth-low risk category. European Union was the least desirable destination falling in the low growth-high risk category. No market was found falling in the most desirable high growth-low risk category (Fig. 2) and hence efforts should be more concentrated towards countries falling under less desirable category having high growth like South-east Asia, USA and Middle East countries with trade and non-trade barriers at ceteris paribus.

Forecasting of marine products export from India

ARIMA model was used for forecasting of agricultural production by several workers in the past. Suresh and Priya (2011); Bajpai and Venugopalan (1996) and Yaseen et al. (2005) used the model for forecasting

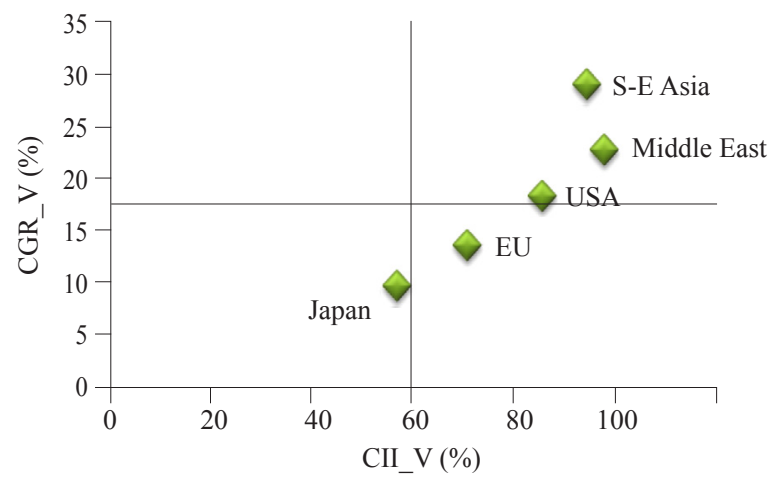

Fig. 2. Growth $v s$ instability of Indian marine products export in terms of value 
production and productivity of sugarcane. Balanagammal et al. (2000) used ARIMA model to forecast the cultivable area, production and productivity of various crops in Tamil Nadu. Boken (2000) and Saeed et al. (2000) used the model for forecasting wheat production. The model was also used to obtain seasonal forecast of paddy and food grains by Balasubramanian and Dhanavanthan (2002). ARIMA model was used for modelling and forecasting of fish catches by Venugopalan and Srinath (1998) and Tsitsika et al. (2007). ARIMA models were also used in forecasting of milk, fat and protein yields of Italian Simmental cows (Maccioitta et al., 2000; 2002). Forecasting of irrigated crops like potato, mustard and wheat was done using ARIMA models by Sahu (2006). Pal et al. (2007) used time-series modelling techniques to forecast milk production in India. Present study attempted to forecast marine products export from India. Prior to forecasting, stationarity check revealed that marine products export time series was not stationary. It was made stationary by using the first order differentiation technique. For different values of $\mathrm{p}$ and $\mathrm{q}(0,1$ or 2$)$, various ARIMA models were fitted and appropriate model was chosen corresponding to minimum value of the selection criterion i.e. RMSE, MAE, MAPE and BIC. In this way, ARIMA $(1,1,0)$ model was found appropriate for marine products export of India (Table 3). The model indicated that the marine products export during any year is weighted function involving marine products export during two preceding years.

After model fitting, next step was diagnostic checking of the fitted model. Auto correlation function (ACF) and partial auto correlation function (PACF) were plotted for residuals of the fitted model. In the present study, ACF and PACF were lying within the limits (Fig. 3). The diagnostic checking of the selected model was also done by comparing CGR and CII for the observed and predicted

Table 3. ARIMA summary statistics for marine products export of India

\begin{tabular}{llll}
\hline Model statistic & ARIMA $(0,1,0)$ & ARIMA $(0,1,1)$ & ARIMA $(1,1,0)$ \\
\hline R square & 0.98 & 0.98 & 0.98 \\
RMSE & 40796.22 & 40621.50 & 40564.12 \\
MAE & 26197.72 & 26174.02 & 25638.53 \\
MAPE & 10.00 & 10.130 & 9.99 \\
Normalised BIC & 21.62 & 21.53 & 21.52 \\
AR lag 1 & --- & -- & 0.20 \\
\hline
\end{tabular}

marine products export of India. As evident from Table 4, there was small difference between CGR and CII values for the observed and predicted marine products export of India and there was no significant difference of CGR and CII for observed and predicted values which further added to the fitness of the model.

Table 4. Comparison of CGR and CII and correlation observed vs predicted quantity of marine products export (1975 to 2014)

\begin{tabular}{lllll}
\hline Parameters & $\begin{array}{l}\text { Observed } \\
\text { value }\end{array}$ & $\begin{array}{l}\text { Predicted } \\
\text { value }\end{array}$ & $\begin{array}{l}\text { Standard } \\
\text { error }\end{array}$ & Variance \\
\hline CGR & 7.88 & 7.69 & 0.0074 & 0.004321 \\
CII & 51.87 & 51.12 & 0.0052 & 0.000652 \\
\hline
\end{tabular}

"Indicates significant at 5\% level and "*indicates significant at $1 \%$ level of significance

Before attempting forecasting, predicted values of last two observations were compared with actual observed values. Observed and forecasted values for each data set are quite close to each other (Table 5). This further strengthens the appropriateness of the identified model. Finally, the marine products export from India was forecasted for eight more years (Table 5), ceteris paribus. Based on the model, it is observed that marine products export of India showed increasing trend in the forecasted years.

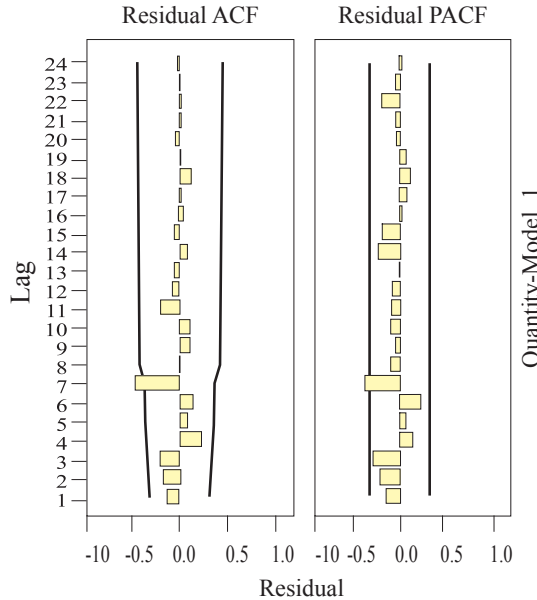

(a)

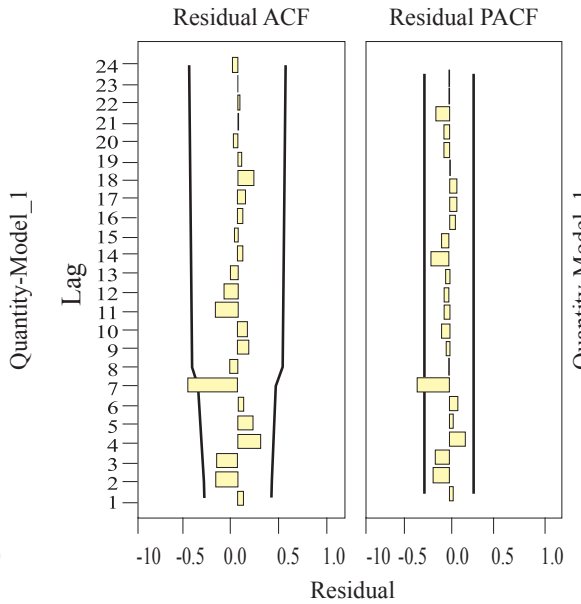

(b)

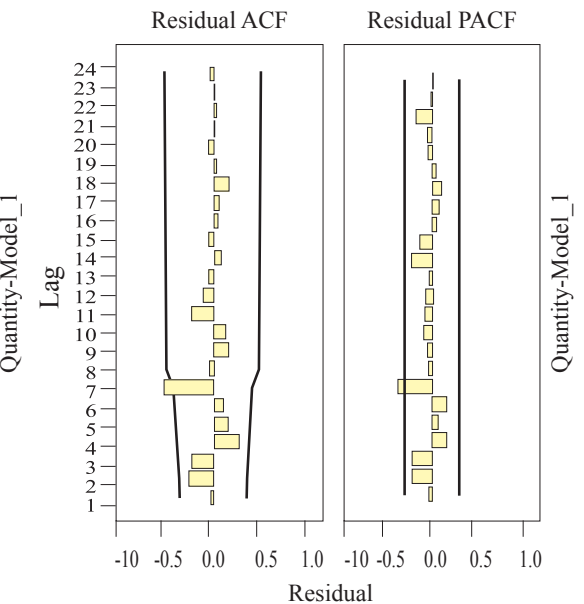

(c)

Fig. 3. ACF and PACF diagrams for (a): $\operatorname{ARIMA}(0,1,0)$; (b): $\operatorname{ARIMA}(0,1,1)$; (c) : $\operatorname{ARIMA}(1,1,0)$ 
Table 5. Forecast value for marine products export of India

\begin{tabular}{lll}
\hline \multirow{2}{*}{ Period/Year } & \multicolumn{2}{l}{ Marine products export (Quantity in t) } \\
\cline { 2 - 3 } & Observed & Predicted \\
\hline 2013 & 983756 & 982106 \\
2014 & 1051243 & 1040986 \\
2015 & --- & $1108754^{*}$ \\
2016 & --- & $1169513^{*}$ \\
2017 & --- & $1231730^{*}$ \\
2018 & --- & $1295647^{*}$ \\
2019 & --- & $1361231^{*}$ \\
2020 & --- & $1428488^{*}$ \\
2021 & --- & $1497416^{*}$ \\
2022 & --- & $1568015^{*}$ \\
\hline
\end{tabular}

"Forecast values

From the results of the present study, it is evident that export growth in terms of quantity and value was low. However, no negative growth was experienced for any destination country in terms of quantity and value. The study also showed that marine products export from India mainly focused to less desirable and least desirable destinations. Instability index indicated that marine products export from India was highly unstable and results of ARIMA model showed an increasing trend in forecasted quantity of export in future. This calls for attention by policy makers to identify competitive and stable market destinations for marine products export. Since no country was identified in the most desirable category, efforts should be more concentrated towards the countries falling under less desirable category which have high growth like South-east Asia and Middle East with trade and non-trade barriers at ceteris paribus. However, measures to stabilise export may go a long way in reducing instability in marine products export from India. Successful identification of stable markets and stabilisation measures will help to enhance foreign exchange earnings and also would help to boost the economy of the country.

\section{Acknowledgements}

The authors sincerely thank the Director, ICAR-Central Institute of Fisheries Education, Mumbai for providing necessary facilities to carry out the study. The authors are also thankful to the anonymous reviewers for their valuable suggestions for improvement of the paper.

\section{References}

Bajpai, P. K. and Venugopalan, R. 1996. Forecasting sugarcane production by time series modelling. Indian J. Sugarcane Technol., 11(1): 61-65.

Balanagammal, D., Ranganathan, C. R. and Sundaresan, K. 2000. Forecasting of agricultural scenario in Tamil Nadu. A time series analysis, J. Indian Soc. Agric. Stat., 53(3): 273-286
Balasubramanian, P. and Dhanavanthan, P. 2002. Seasonal modelling and forecasting of crop production. Stat. Appl., 4(2): $107-118$

Boken, V. K. 2000. Forecasting spring wheat yield using time series analysis: A case study for the Canadian prairies. Agric. J., 92(6): 1047-1053.

Bryan, M. F. and Cecchetti, S. G. 1993. The consumer price index: As a measure of inflation. Paper no. 4505, National Bureau of Economic Research, Cambridge, p. 15-19.

Chand, R. and Tewari, S. C. 1991. Growth and instability of Indian exports and imports of agricultural commodities. Indian J. Agric. Econ., 46(2): 159-165.

Coppock, J. D. 1962. International economic instability. McGraw-Hill, New York.

Fauzi, A. 2012. Growth and instability of small pelagic fisheries of the north coast of Java, Indonesia: Lesson learned for fisheries policy. China-USA Business Review, 11(6): 739-748.

Hanson, J. V., Macdonald, J. B. and Nelson, R. D. 1999. Time series prediction with genetic-algorithm designed neural networks: An empirical comparison with modern statistical models. Comput. Intel., 15(3): 171-184.

Indiastat 2016. Export of marine products from India, Ministry of Agriculture and Ministry of Statistics and Programme Implementation, Government of India. http://www.indiastat. com/foreigntrade/12/agriculturalexport/449482/marine productsexport/18083/stats (Accessed 10 December 2016].

Jeyanthi, P. and Nikita, G. 2012. Growth and instability in Indian frozen scampi export, Fishery Tech., 49: 187-192.

MacBean, A. I. 1966. Export instability and economic development. Harvard University Press, Cambridge.

Maccioitta, N. P. P., A. Cappio-Borlino and Pulina, G. 2000. Time series autoregressive integrated moving average modelling of test-day milk yields of dairy ewes. J. Dairy Sci., 83: 1094-1103.

Maccioitta, N. P. P., Vicario, D., Pulina, G. and Cappio-Borlino, A. 2002. Test-day and lactation yield predictions in Italian simmental cows by ARMA methods. J. Dairy Sci., 85: 3107-3114.

Massell, B. F. 1970. Export instability and economic structure, American Econ. Rev., 60: 618-630.

MPEDA 2016. Marine products exports from India during 2014-15. http://www.mpeda.com/inner_home.asp?pg=trends (Accessed 9 December 2016).

Pal, S., Ramasubramanian, V. and Mehta, S. C. 2007. Statistical models for forecasting milk production in India. J. Indian Soc. Agric. Stat., 61(2): 80-83.

Parthasarathy, G. 1984. Growth rates and fluctuations of agricultural production: A district-wise analysis in Andhra Pradesh. Econo. Polit. Weekly, 19(26): 74-84.

Reddy, A., Amarendra and Mishra, D. 2010. Growth and instability in chickpea production in India: A state level 
analysis. http://ssrn.com/abstract=1499577 (Accessed 27 June 2013).

Saeed, N., Saeed, A., Zakria, M. and Bajwa, T. M. 2000. Forecasting of wheat production in Pakistan using ARIMA models. Int. J. Agric. Biol., 2(4): 352-353.

Sahu, P. K. 2006. Forecasting yield behaviour of potato, mustard, rice and wheat under irrigation. J. Vegetable Sci., 12(1): 81-99.

Salim, S. S. and Biradar, R. S. 2009. Indian shrimp trade: reflections and prospects in the post WTO era, Asian Fish. Sci., 22: 805-821.

Sarada, C., Ravishankar, T., Krishnan, M. and Anandanarayanan, C. 2006. Indian seafood exports: Issues of instability, commodity concentration and geographical spread. Indian J. Agric. Econ., 61(2): 238-252.

Singh, A. J. and Byerlee, D. 1990. Relative variability in wheat yields across countries and over time. J. Agric. Econ., 14(1): 21-32.

Suresh, K. K. and Priya, S. R. K. 2011. Forecasting sugarcane yield of Tamil Nadu using ARIMA models. Sugar Tech., 13(1): 23-26.
Tsitsika, E. V., Maravelias, C. D. and Haralabous, J. 2007. Modelling and forecasting pelagic fish production using univariate and multivariate ARIMA models. Fish. Sci., 73: 979-988.

Venugopalan, R. and Srinath, M. 1998. Modeling and forecasting fish catches: Comparison of regression, univariate and multivariate time series methods. Indian J. Fish., 45(3): 227-237.

Wasim, M. P. 1999. Growth rates and fluctuations in area, production and productivity: A study of major crops in Sindh-Pakistan, Pakistan Econ. Social Rev., 37(2): 155-168.

Wasim, M. P. 2007. Issues, growth and instability of inland fish production in Sindh (Pakistan) - spatial-temporal analysis. Pakistan Econ. Social Rev.,45(2): 203-230.

Weber, A. and Sievers, M. 1983. Observations on the geography of wheat production instability. J. Int. Agr., 24(3): 201-211.

Yaseen, M., Zakria, M., Islam-ud-din-Shahzad, Imran K. M. and Aslam J. M.2005. Modeling and forecasting the sugarcane yield of Pakistan. Int. J. Agric. Biol., 7(2): 180-183. 